\title{
Native and Non-native Saints in Eighteenth and Nineteenth-Century Irish-Language Charm Historiolas
}

\author{
Nicholas Wolf \\ Historian and Librarian, NYU Library's Data Services Department \\ and Faculty of Glucksman Ireland House, New York University, USA
}

\begin{abstract}
An examination of surviving healing charm texts originating in Ireland between 1700 and the mid-nineteenth century suggests a strong link between the contents of this corpus and a select few national saints (Columcille, Bridget, and Patrick) and international Catholic religious figures (Christ, Mary, and the Apostles). By contrast, local Irish saints, which otherwise figure so prominently in religious practices of the time, are significantly underrepresented in the Irish charm corpus of this time period. This essay looks at the long-term status of highly localized saints in religious and medical discourse, the effect of church centralization in the late eighteenth and early nineteenth century, and the rise of select national saints as factors in this feature of the Irish charms.
\end{abstract}

Keywords: Irish charms, Irish saints, eighteenth-century charm practices, nineteenth-century charm practices, Saint Columcille, medical charms, healing charms

Discussion of religious figures appears consistently in surviving charm examples from the medieval period to the present, with key Christian figures such as Jesus, Mary, and the saints featuring heavily in the European corpus from which many of the readily identifiable international charm types have been derived. One of the most widely circulated charms, for example, the Super Petram type, features Jesus assisting St. Peter, who has been struck by toothache, by enabling his removal from a marble or stone seat. Another, the Crux Christi type, centres on the parallels between the trembling of Christ as he neared crucifixion and the shaking induced by fever to enable the curing of the patient's illness. The prevalence of historiolae in charm texts, in which short descriptions of events or actions seem to symbolize the loosening of illness from the afflicted or the blocking of sickness in the first place, was particularly suited to the popularity of saints' lives in European culture, epitomized by texts such as the Legenda Aurea, or Golden Legend, by Jacobus de Voragine, compiled in 1275 in manuscript form and one of the most popular printed books by the fifteenth century. The format of these lives, with collated short episodes of saintly deeds, closely echoes many of the similarly short episodes that lie at the centre of charm texts featuring such figures. 
In Ireland as well, Christian figures, including saints, were a salient aspect of the charm corpus that has been compiled, spanning the ninth (and possibly earlier) to the twentieth centuries. Indeed, we might expect saints - and local saints in particular - to feature heavily in the Irish corpus given the sheer number of native holy figures that populated the medieval Irish landscape. In this, Ireland was not alone, as the proliferation of local saints across the landscape of Rome-centred Christendom, particularly in early Christian times, is well known to scholars. As anthropologist Lawrence Taylor has noted, however, Ireland also had in common with other more fringe geographical locations in Christian countries the tendency to focus on eremitic monasticism, with its love of harsh, barren environments as a place to site monasteries or engage in ascetic isolation (TAYLOR 1995:40-41). From these monks were derived the dense legions of early Irish saints, often as many as one or two per locality, in a focused cult of sainthood that usually included an associated holy well and a community of adherents that T. M. Charles-Edwards has suggested evolved into the parish in the late medieval period (CHARLES-EDWARDS 2004:81).

A few features of this slate of thousands of saints are relevant to the larger question of religious figures in charms, in particular because of the contrast between their large numbers and the relatively limited number of Christian persons that appear in exemplars of the later charms. There is the mobility and rootlessness of these saints, a function, as Taylor notes, of their origins in a tribalistic people driven by animal-husbandry, such as was prevalent in early Irish society of the ancient and medieval period. In fact, to this day only a handful of Irish individuals received sainthood through an official process. Instead, they achieved sainthood through local church acclamation in the period pre-dating the creation of centralized Roman entry points to canonization. Moreover, their hagiographic accounts are filled with discussions of wild adventures and endless wanderings undertaken by the saints, more akin to Irish hero-tales of the famous Ulster or Fenian cycles than to those of the later Italian-centred church. So limited was the reach of these saints that in some cases they do not appear in any surviving episodes in the Lives. Nor have they more than a single church (or cille) associated with them, suggesting that their renown extended no farther than the intensely local population who provided participants for the religious figure's cult.

Despite this local reach, all of the ingredients would appear to be in place for these religious figures to serve as protagonists in charm historiolae. Local Irish saints worked numerous healing miracles in the accounts of their lives, and their personalities strike modern ears as robust, almost warrior-like figures adept at vanquishing enemy forces that threatened the early Christian community, whether sickness or disbelief. The imagery of blockage, release, and striking at sickness so common in charms would seem to be a perfect match for these saints. Nevertheless - and this comes to the heart of this essay the surviving charm corpus does not strongly feature Ireland's local saints, at least not when we come to the charms of the modern period, from 1700 onward. By contrast, local religious figures, whether Christian or pre-Christian, were not unknown in the surviving medieval corpus. The $c$. ninth-century St. Gall codex and the tenth- or eleventh-century Stowe Missal, for example, cite the deity Goibniu, a metal smith Celtic god akin to Vulcan; the native healer Dian Cécht; and Saint Íbar (STOKes - Strachan 1975:2:24849; TuOMI 2013; Borsje 2012:204-206; 2016:40). A native healer from the Ulster hero cycle is indirectly referenced in an impotency charm of medieval provenance, and Saint Áed in an early Latin-language charm for headaches (BERNHARDT-House 2007; CAREY 
2004:19-21; Best 1952:32; SChlutter 1899:71-74; Stokes 1890:324). Even for this early period, however, non-Irish figures like Christ and Paul, and even Old Testament names such as Isaiah, Solomon, and Abraham, appear as often in the surviving examples. In addition, later fifteenth- and sixteenth-century charm texts seem to exhibit a trend toward non-local figures - though further research is needed - with abundant references to St. Luke, Mary, and the trio of Irish national saints, Bridget, Patrick, and Columcille, but not the local saints who otherwise figure so prominently in Irish folk healing and belief cultures. ${ }^{1}$

For the modern charms of the last three hundred years, a similar focus on Christ, Mary, the Apostles, and the Irish national saints Bridget, Patrick, and Columcille is also noticeable. I have not found any mention of a locally based saint among the 79 charms I have examined in eighteenth- and nineteenth-century Irish-language manuscripts to date, nor do they appear among the first lines of charms catalogued in other studies of Irish charm types. ${ }^{2}$ This would indicate that of a corpus of over 300 charm texts, and likely closer to 350 or 375 once the handful of charm reliquaries is fully examined, the number of religious figures with local (as opposed to national) connections among the surviving Irish charm texts of the modern period will be disproportionately small or nearly non-existent. This is not to say that specifically Irish themes do not exist in the corpus - Irish place names and family names are referenced, for example - but that charm texts of this period tend to be, by and large, a question of generically international historiola combined with a strong focus on the three national saints Patrick, Bridget, and Columcille.

On one level, this should not be a surprising state of affairs. The larger Irish historical context concerning religious developments in the two centuries leading up to 1900 mitigated strongly against the featuring of local saints in religiously tinged, more general cultural practices. Most saliently, local saints had all too often been side-lined by the early modern, and certainly by the modern period, by the growing cult dedicated to the national saints cited above, not to mention the generic Christianity symbolized by figures like Christ, Mary, and Peter. Taylor, for example, citing the work of William Christian in the 1970s on similar displacement of local saints in the Spanish context, and Peter Harbison's investigation of the transference of the object of local pilgrimages and other rituals away from early Christian and pre-Christian figures, highlights this trend toward nationally recognized individuals such as Columcille. This shift, in turn, had its ramifications for healing practices, most notably the holy wells that were dedicated to saints and possessed healing properties for those who performed turas (penitent rounds) at the well sites and ingested the waters (TAYLOR 1995:43-45). With the arrival of the so-called Irish Catholic "devotional revolution" of the nineteenth century, and with it an even greater emphasis by church officials on alternate, respectable forms of religiosity, the wells were subject to scrutiny, and in many cases closure, by religious authorities. The

1 CARNEY - CARNEY 1961:144-145. Note also the alternate translations for aspects of these charms offered in STIFTER 2007.

2 The majority of these charms have been located in the Gaelic manuscript collections of the National Library of Ireland and Royal Irish Academy (RIA). The RIA manuscripts have also been the source of a catalogue of charms found within this collection by CHAMPAGNe 2001. Additional charms have been identified in print publications, most notably HYDE 1972. 
preferred alternative in this period - private prayer, mass attendance, and internationally recognized chapel-centred forms of worship - represented yet another denial of local saints in favour of internationally acceptable prayers and liturgical responses based around Marian, or at least canonically recognized, figures.

The overall transformation in Irish Catholic religious practices in the eighteenth and nineteenth centuries - particular in the latter as the loosening of legal restrictions on Catholic property ownership paved the way for a strong program in church building and clerical instruction, both essential to a reassertion of centralized control over expressions of religiosity - were not the only factors that may have influenced the forms that charms in Ireland took in this period. The Irish church was increasingly clerically dominated and universalized (owing to its centralization) in its characteristics. It was also increasingly Marian as mainland European interest in such devotions, cemented by the apparition at Lourdes in 1858, consolidated strength. The popularity of the Sodality of the Children of Mary and the Marian characteristics of the Catholic parish mission movement that took hold in Ireland in mid-century contributed to the growth of these forms of worship in Ireland (DonNelly 1993). With so much focus on Mary, local religious figures were once again prone to displacement, and we might expect the same among surviving charms texts.

The final development in the modern period, with antecedents in the sixteenth and seventeenth centuries, which contributed to the elevation of saints such as Patrick, Bridget, and Columcille, was the perpetuation of a new generation of Tridentine publication of saints' lives and catechetical treatments of Catholic practice that performed precisely this service. As Bernadette Cunningham and Raymond Gillespie have explained, the need for enthusiasts of the Irish place in global Catholicism to ensure the prominence of Irish saints in a new world of verifiable miracles and established lines to canonization meant a flurry of activity to reshape these three saints as representative of the great tradition of Irish Christianity for a post-Trent audience. Thus, key publications by Thomas Messingham and John Colgan on the lives of saints served to expand on the repertoire of miracleworkings by Patrick, Bridget, and Columcille, and also to elevate their position as native missioners for the Irish Catholic church over others (CUNNINGHAM - GILLESPIE 1995:90, and 93-97). Given that these written lives experienced considerable popularity in the eighteenth and nineteenth century within the very same Irish-language manuscripts that contain so many of the existing charm exemplars, it would seem natural for these saints to be so much more intimately connected with charm practices than the thousands of other Irish saints that might have figured in the corpus. ${ }^{3}$

Columcille seems to receive strong attention in the surviving charm corpus of the eighteenth and nineteenth centuries. He can be identified in at least a dozen charm instances, a larger concentration than that of either St. Patrick or St. Bridget. A lateeighteenth-century manuscript assembled by Fearghal Ó Raghallaigh in either County Meath or County Cavan in the 1790s provides one such example in a charm for a mote in the eye:

3 On the popularity of Patrick, Bridget, and Columcille in the Irish-language writing of these two centuries, see WOLF 2014:199-201. 
"Othra chuir Muire le súil Cholum Cille, air bhroth, air bhrínnin, air cholg, air choinnlíon, air sgúaba láir, ar smár [? smál?] líon, air duradan, no nídh air bith eille, iaruim ar rúgh na ndíuil [sic] cebe ta inn do thsúil go ceasaidh sé inn mo bhéul" (British Library MS Egerton 155, art. 17).

[A charm that Mary put on the eye of Columcille, on the hot eruption(?), on a spine, on a stalk, on a floor broom, on a blot of linen, on the mote, or anything else, I ask (...) whatever is in your eye to be transferred to my mouth.]

Remedies for thorns, dog bites, toothaches, and especially eye ailments are the charm functions most well-represented in the Columcille charms, all of which fall within medical themes. This focus on healing capabilities is in keeping with the trends that accompanied the general rise of the cults of saints Bridget, Patrick, and Columcille in the Tridentine context. Modern hagiographical understandings of these figures likewise focused on their miraculous powers, prophetic abilities, and, in the case of Patrick, patriarchal position as representative of the Irish Church. All three saints acquired a strong following in folklore practices in general, as in the widespread use of the protective straw objects known as cros bride, or St. Bridget's cross. ${ }^{4}$

Columcille in particular acquired a reputation as an effective saint to receive petitions for healing as well as harm (LACEY 1997:95). Born by all accounts in Donegal in the early sixth century, and alternatively known as Saint Columba, the saint was a member of the powerful Uí Néill family that would completely dominate the northern Ulster province of Ireland until the early seventeenth century. Fostered by a priest, and thus clearly intended for the church at an early age, Columcille is believed to have founded his major monastic settlement on the island of Iona off the coast of Scotland around 563. His principle biographies are the Latin life written by Adomnán, an abbot of Iona, in the late seventh century, and the expansive Irish-language modern life written by Magnus Ó Domhnaill in the sixteenth century. Tellingly, whereas Adomnán's life had been sparse on biographical details and focused on his piety and prophecies, offering an impression of a firm monastic founder and even a figure prone to anger, Ó Domhnaill and his team of scholars assembled what has been deemed an "encyclopedic" compendium of everything known or believed about the saint (BREEN 2009; LACEY 1997:93). Thus, it is the later life that has been packed with all manner of miracles, activities, and events, and where more fruitful connections between the themes and functions of the charm corpus and Columcille's life can be uncovered.

One episode from the life by Ó Domhnaill resonates with the frequent association of Columcille with charms cures for the eye. In this episode, a member of the religious community comes to Columcille while he is resident in Scotland, seeking a remedy for the ailing eyes of his mother and sister. The saint prescribes placing salt that he has blessed in water and applying that water to the eyes, yielding a restoration of their health. The salt is then described as having further protective powers against fire, such that the vessel in which it has been kept survives a devastating fire that occurs days after the healing. A magic salt that cannot succumb to fire is also described in the life by Adomnán, but whereas certain themes in that story - the receiving of the blessed salt by two women,

4 On St. Bridget crosses, see O’Dowd 2015. 
for example - were clearly adapted by Ó Domhnaill, the power of Columcille to heal eyesight does not appear in the earlier life (O'Kelleher - SchoepPerle 1994:275; REEVES 1874:42-43). While this episode is by no means replicated in the charm corpus - in fact, in the most common eye ailment charms discussing Columcille, as in the one offered above, it is Mary who applies the remedy to Columcille, not the reverse - it does give an indication of the medical powers that were believed to have accrued to the saint, especially by the later period.

In the final estimation, instances of religious figures as an indicator of the mobility of charms is no different from the presence of other entities, like place names. That few local saints appear in the Irish charm texts in contrast to the frequent appearances of Bridget, Patrick, and Columcille strengthens our sense that charms - or at least the examples that survived in charm texts - by their nature moved long distances in their transmission, necessitating (or inserting) nationally or internationally known persons in place of hyperlocal figures. This does not necessarily exclude the presence of local religious figures in some charms that simply have not survived, and we should trust that a charm text that persists may very well be more likely to have been transmitted more often and at greater distance, enabling such endurance. Still, that conclusion also reinforces the prevalence and popularity of the surviving charm texts precisely because of their mobility, again affirming our sense that it was generic and universal figures who were most favored in the later charms. The dominance of Patrick, Bridget, Mary, Columcille, Peter, Luke, Paul, and Christ in the Irish charms also hints that many had taken the form found in the eighteenth- and nineteenth-century corpus at a relatively recent date, given the rise of Marianist cults and of the saintly Irish trio in the early modern and especially the post1700 period. Once again, charms prove to be at the same time extremely ancient in their roots and persistence, and yet always mutable and contemporary in their content and use.

\section{REFERENCES CITED}

Bernhardt-House, Philip A.

2007 The Old Irish Impotence Spell: The Dam Díli, Fergus, Fertility, and the Mythic Background of an Irish Incantation. Journal for Academic Study of Magic 4(October):304-324.

BEST, Richard Irvine

1952 Some Irish Charms. Ériu 16:27-32.

BORSJE, Jacqueline

2012 The Celtic Evil Eye and Related Mythological Motifs in Medieval Ireland. Leuven: Peeters.

2016 Medieval Irish Spells: "Words of Power" as Performance. In Hemel, Ernst Van Den - Szafraniec, Asja (eds.) Words: Religious Language Matters, 3553. New York: Fordham University Press.

BREEN, Aidan

2009 Colum Cille (Columba). In McGuiRE, James - Quinn, James (eds.) Dictionary of Irish Biography. Cambridge: University of Cambridge Press. http://dib. cambridge.org/viewReadPage.do?articleId=a1890. (accessed May 7, 2019). 
CAREY, John

2004 The Encounter at the Ford: Warriors, Water, and Women. Éigse 34:10-24.

CARnEY, James - CARneY, Maura

1961 A Collection of Irish Charms. Saga och Sed 1961:144-152.

Champagne, Kelly

2001 A Catalogue of Charms in the Royal Irish Academy Manuscripts. M.A. Dissertation, Department of Celtic, University of Edinburgh.

Charles-Edwards, Thomas Mowbray

2004 Early Irish Saints' Cults and Their Constituencies. Ériu 54:79-102.

Cunningham, Bernadette - Gillespie, Raymond

1995 "The Most Adaptable of Saints": The Cult of St. Patrick in the Seventeenth Century. Archivium Hibernicum 49:82-104.

DONNELLY, James S.

1993 Jr. The Marian Shrine of Knock: The First Decade. Éire-Ireland 28(2):55-64. HYDE, Douglas

1972 Adhráin Diadha Chúige Connacht: The Religious Songs of Connacht. 2 Vols. Shannon: Irish University Press. (1906).

LACEY, Brian

1997 Colum Cille and the Columban Tradition. Dublin: Four Courts Press.

O’Dowd, Anne

2015 Straw, Hay, and Rushes in Irish Folk Tradition. Dublin: Irish Academic Press.

O'Kelleher, Andrew - Schoepperle, Gertrude (eds.)

1994 Betha Colaim Chille: Life of Columcille Compiled by Maghnas Ó Domhnaill in 1532. Reprint. Dublin: Dublin Institute for Advanced Studies. (1918).

REEVES, William (ed.)

1874 Life of Saint Columba, Founder of Hy, Written by Adamnan, Ninth Abbott of That Monastery. Edinburgh: Edmonston and Douglas.

SCHLUTTER, Otto B.

1899 An Irish-Latin Charm. American Journal of Philology 20(1):71-74.

STIFTER, David

2007 A Charm for Staunching Blood. Celtica 25:251-254.

Stokes, Whitley (ed.)

1890 Lives of Saints from the Book of Lismore. Oxford: Clarendon Press.

Stokes, Whitley - Strachan, John (eds.)

1975 Thesaurus Palaeohibernicus: A Collection of Old-Irish Glosses, Scholia, Prose, and Verse, 2 Vols. Reprint ed. Dublin: Dublin Institute for Advanced Studies. (Cambridge: Cambridge University Press, 1901).

TAYLOR, Lawrence J.

1995 Occasions of Faith: An Anthropology of Irish Catholics. Philadelphia: University of Pennsylvania Press.

TuOMI, Ilona

2013 Parchment, Praxis, and Performance of Charms in Early Medieval Ireland. Incantatio 3:60-85.

Wolf, Nicholas M.

2014 An Irish Speaking Island: State, Religion, Community, and the Linguistic Landscape in Ireland. Madison: University of Wisconsin Press. 
Nicholas Wolf is a historian and librarian at New York University, where he is a member of NYU Library's Data Services department and an affiliated faculty of Glucksman Ireland House. He is the author of An Irish-Speaking Island (2014), a social and cultural history of Ireland's Irish-language community in the eighteenth and nineteenth centuries that was awarded the Michael J. Durkan Prize for Books on Language and Culture and the Donald Murphy Prize for Distinguished First Books. His research into the social and cultural history of the Irish language, Irish Catholicism, and Ireland's population history has received grants and fellowships from the National Endowment for the Humanities, New York University's University Research Challenge Fund, the Newberry Library, and Newman College at the University of Melbourne. E-mail: nicholas.wolf@nyu.edu 